Corrective feedback preferences among Iranian EFL

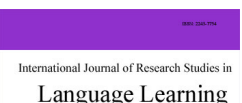
students

Yousefi, Valiollah

Department of English Language, Islamic Azad University, Science and Research Branch, Iran (Yousefi1234@gmail.com)

\title{
Abstract
}

The present study investigates the patterns of corrective feedback and negotiated feedback present in senior-level adult ESL classrooms. To this end, a topic was presented for discussion and everyone was permitted to express their own viewpoints. The data were collected through actual classroom observations (audio-taped) and follow-up interviews. The findings of this study showed that based on classroom observations and transcribing the data, the most frequent type of corrective feedback was 'clarification request', which comprises 8 (32\%) feedbacks out of 25 and the least frequent feedback was 'explicit correction' receiving no consideration. Finally, follow-up interviews with students demonstrate that there is conformity between their preferences and the actual classroom feedback given.

Keywords: feedback; corrective feedback; oral feedback; clarification request; explicit correction 


\section{Corrective feedback preferences among Iranian EFL students}

\section{Introduction}

From long ago the educationists were to find a way to enhance learning development. One way they adhered to was to focus on learners' oral or written output in order to better understand the learners' knowledge in specific areas of language learning. So, one of the areas in which second language teachers were interested was errors produced by learners as an evidence showing a problem in their interlanguage system. In this vein, second language teachers attempt to feedback to learners' errors either to correct them or to motivate learners to be aware of them. Therefore, in order to address the errors, teachers have a wide variety of treatment strategies to the students' errors (Lyster \& Ranta, 1997). 'Whether and how to correct errors usually depends upon the methodological perspective to which a teacher ascribes' (Russell, 2009, p. 21). Russell (2009) believes that historically error correction can be classified in the following stages:

$>\quad$ The behaviorist era in the 1950's and 1960's stressed error correction inevitable, but strove to avoid and overcome them by providing speedy examples of correct responses (e.g. Brooks, 1966).

$>\quad$ In the 1970s and 1980s, error correction was not only unnecessary, but also harmful to SLA (e.g. Dulay and Burt, 1973, 1974; Krashen, 1981, 1982; Terrell, 1977, 1982).

$>\quad$ In the 1980 s, by the emergence of CLT, the focus was drawn on meaning rather than form (e.g. Richards \& Rodgers, 1986; Omaggio Hadley, 2001). the correction of grammatical errors is not of primary importance.

$>\quad$ In the 1990s onward, some researchers began to assert that explicit grammar instruction, error correction, and/or a focus on form could promote SLA (Aljaafreh \& Lantolf, 1994; Doughty \& Varela, 1998; Ellis, 1993, 1994; Fotos, 1994; Long, 1996; Schmidt, 1990, 1993, 1995; Sharwood Smith, 1993). According to Long (1996), negative evidence, or what is not possible in a language, is vi-tally important for L2 acquisition, especially among adolescent and adult L2 learners.

'Feedback has long been regarded as essential for the development of second language (L2) writing skills, both for its potential for learning and for student motivation' (Hyland \& Hyland, 2006, p. 83) . Corrective feedback (hereafter, CF) is a pedagogical technique teachers use to draw attention to students' erroneous utterances, and which may result in learners' modified output (Suzuki, 2004).

'Teachers in-class CF on their students' oral second language (L2) production has received considerable attention over the past 20 years (Lee, 2013, p.217). In addition, studies on CF in second language (L2) classrooms and ESL settings have verified its characteristics and role in L2 teaching and learning (Lyster \& Ranta, 1997; Doughty \& Varela, 1998; Oliver, 2000; Panove \& Lyster, 2002).

Regarding the functions and impacts of feedback in classroom, while sometimes written feedback is implemented in classroom, most of the time due to some limitations of written feedback such as shortage of time, loss of oral communication, and limited scope of considered knowledge, teachers and practitioners have to focus on the learners' oral skills (speaking and listening) as precisely as possible to evaluate and interact with them in time. So, this study aims to investigate the efficacy of feedbacks in second language (SL) oral skills. Although to date, very few studies have examined the efficacy of negotiated feedback or scaffolded feedback (Weissberg, 2006) in L2 writing, there are few evidences demonstrating the efficacy of feedbacks in SL oral skill. Since the focus of the study is communicating meaning and content rather than structure. 


\section{Review of literature}

\subsection{Error significance}

When the views on errors in second language learning changed from the contrastive analysis (CA) to error analysis (EA), errors were conceptualized as facilitative elements for learners and teachers. In same line Corder (1967, p. 167) discusses the significance of errors as follows:

$>$ They tell teacher, if he undertakes a systematic analysis, how far toward the goal the learners have progressed, and as a result, what remains for them to learn.

$>$ They provide researchers with evidence of how language is learnt or acquired, what strategies or procedures the learner is employing in his discovery of the language.

$>$ They are indispensable to learners themselves, because we can regard the making of errors as a device the learners use in order to learn through hypothesis testing.

Thornbury (2006, p. 75) defines error as "an instance of the learner's language that does not conform to accepted norms of usage and which is attributed to incomplete or faulty learning".

\subsection{Feedback}

Feedback is an explicit or implicit strategy for an attainment in SLA which can be negative or positive. Feedback has been defined differently. According to Pica (1994, cited in Birjandi \&Tabatabaei, 2009), 'feedback is the information that learners receive about their language production, and gives them the opportunity to modify their output.' (p. 60). Keshavarz (1999) believes that feedback is 'the response to efforts by the learner to communicate' (p. 152). Regarding different functions of feedback, Keshavarz (1999) states that 'feedback can involve such functions as correction, acknowledgment, and request for clarification [and it] plays a major role in helping learners to test hypotheses they have formed about the rule system of the target language' (p. 152).

The gap between what is understood and what is aimed to be understood can be specified by feedback (Sadler, 1989). Feedback can be positive or negative. Mackey (2012) makes a distinction between positive evidence, negative evidence, feedback, and error correction. Mackey also believes that feedback is 'a mechanism by which linguistic information (i.e. evidence) is provided to the language learner' (p. 114). According to Leeman (2007, cited in Mackey, 2012, p. 114), the mechanism can either be positive feedback, which confirms that the process of communication was a 'success', or negative feedback, which confirms that the process of communication was a 'failure'. Nunan (1991), for example, devotes more attention to positive feedback than corrective feedback. He noted that it serves two functions: 'to let students know they have performed correctly' and 'to increase motivation through praise' (p. 195). Winne and Butler (1994) provided an excellent summary in their claim that 'feedback is information with which a learner can confirm, add to, overwrite, tune, or restructure information in memory, whether that information is domain knowledge, meta-cognitive knowledge, beliefs about self and tasks, or cognitive tactics and strategies' (p. 5740). According to Winne and Butler's (1994) conceptualization, feedbacks can be done either in case of content (e.g. belief) or structure (e.g. knowledge).

Oral and Written Corrective Feedback - Sheen (2010, p. 171) argues that 'oral CF research has been largely grounded in SLA theories and hypotheses, whereas written CF research has drawn on L1 and L2 writing composition theories'. Sheen further adds that there are a number of issues common to the study of oral and written CF: (a) whether oral and written CF works, (b) what constitutes the most effective approach for implementing $\mathrm{CF}$, (c) what contextual and individual learner factors contribute to the effectiveness of oral and written $\mathrm{CF}$, and (d) whether it is possible to develop a common methodology for investigating the effectiveness of oral and written CF (p. 171). 'The theoretical significance of CF research is perhaps more evident in the case of oral CF studies' (Ellis, 2010, p. 335). However, different types of written corrective feedback have been 
applied to research studies (Ellis, 2009; Hartshorn et al., 2010; Maftoon et al., 2005; and Nassaji, 2011) based on the following typology (1) direct CF, (2) indirect CF, (3) metalinguistic CF, (4) the focus of the feedback, (5) electronic feedback, (6) reformulation, (7) audio-taped CF, (8) dynamic feedback, and (9) negotiated.

According to Lyster and Ranta (1997), there are six types of oral feedback: recasts, elicitation, clarification requests, metalinguistic feedback, explicit correction, and repetition. Teachers' feedback can be immediately followed by learners' reaction which Lyster and Ranta (1997) called 'uptake'. In other words, uptake is as “a student's utterance that immediately follows the teacher's feedback and that constitutes a reaction in some way to the teacher's intention to draw the learner's attention to some aspect of the student's initial utterance" (Lyster and Ranta, 1997, p. 49). If error correction is teacher-initiated in a single utterance, it is called 'repair' (Lyster \& Ranta, 1997).

Teacher Feedback - Feedback has long been recognized as a crucial feature of the teaching-learning process (Gippse, 1994). Teachers are constantly acting as feedback agents in terms of performance comments. Since these comments are evaluative and fairly frequent, particularly to some children, they will be crucial in confirming self-concept and self-esteem levels (Gurney, 1988). Separating teacher correction from student correction, Sadler (1989) maintains that 'teachers use feedback to make programmatic decisions with respect to readiness, diagnosis and remediation. Students use it to monitor the strengths and weaknesses of their performances, so that aspects associated with success or high quality can be recognized and reinforced, and unsatisfactory aspects modified or improved' (p. 120).

The most effective forms of feedback are those which focus the pupils' attention on their progress in mastering the required task (Gipps, 1994, p. 39). Gipps (1994) considers the following features for teacher feedback:

$>\quad$ It enhances self-efficacy,

$>\quad$ It encourages effort attribution,

$>\quad$ It reduces the focus on comparison with peers,

$>\quad$ It should take place while it is still relevant, i.e., soon after the task is completed,

$>\quad$ And it should be specific and related to need, i.e., simple information about results should be provided consistently (p. 39).

Gipps (1994, pp. 129-130) further puts forth that feedback, in the process of teaching, is considered to be important for two reasons: it contributes directly to progress in learning through the process of formative assessment, and indirectly through its effect on pupils' academic self-esteem. Praise should be used sparingly, and should be task-specific. Above all, criticism is usually counter-productive (Gipps, 1994). This is in line with behaviorists view which divides positive from negative feedback. Based on Chaudron (1988), positive feedback is positive praise or repetition of students' correct responses while negative feedback refers to grammar explanation and modeling of correct responses. Gipps (1994) claims that 'the mere provision of feedback is insufficient for optimal learning; it must also indicate what the pupil can do to improve performance' (p. 131).

Generally speaking, teacher feedback could be categorized in many ways such as 'form-focused' (at sentence level) and 'content-focused' (at meaning level), 'explicit' (explicit provision of the correct form) and 'implicit' or 'recast' (teacher's reformulation of all parts of students' sentences) 'correcting' and 'helping', or 'affective' and 'cognitive' (Chaudron, 1988; Lyster \& Ranta, 1997; Vigil \& Oller, 1976).

Types of Feedback - Moreover, feedback can be either positive demonstrating comprehension of the learner's language or it can be negative pointing out to the learner what was non-target like about his or her utterance (Birjandi \&Tabatabaei, 2009). Positive feedback can be divided in to four categories (Ferreira, Moore, 
\& Mellish, 2007): (1) Acknowledgement, (2) Acceptance, (3) Repetition, and (4) Rephrasing.

Corrective feedback, as Lyster and Ranta (1997, pp. 46-49).) put it, is divided into six categories:

$>$ Explicit correction which is defined as 'any feedback technique that involves a teacher simply providing a student with the correct answer';

$>$ Recast which deals with as 'a more implicit feedback technique that involves the teacher's reformulation of all or part of a student's utterance, minus the error';

$>$ Clarification request is considered as any 'feedback type in which the teacher asks a question indicating to the student that there is a problem with the language utterance';

$>$ Repetition which refers to 'the type of the feedback that involves a teacher repeating wrong utterance highlighting it with intonation';

$>\quad$ Metalinguistic feedback which 'involves a teacher making comments or indicating to the student that there is an error in the language output (e.g., Can you find an error?)';

$>\quad$ And elicitation which stands for 'a feedback type when teachers ask for completion of their own sentence by pausing and allowing students to correct themselves; they may also ask questions to elicit correct form and help students to reformulate an ill-formed utterance.'

The present study aims at investigating the frequency feedback types in terms of oral feedback implemented in an ESL classroom.

\section{Participants}

The participants of this study were 16 senior students majoring English teaching at Buali-Sina University in Hamadan, Iran. The participants were both male and female and their age ranged between 22 and 26. The participants were to take part in oral representation classroom discussing the title 'Children vs. Adult in Second Language Acquisition'. Everyone was supposed to voluntarily express their own idea on the topic of discussion. They were informed previously about the topic to have their own viewpoint in due session. They were also provided with any types of materials to develop their knowledge on the topic. One of the participants was presenting the article via data projection and the instructor and the rest of the participants could participate in the class discussion.

\section{Results}

In order to investigate the frequency of feedback types and specifically the impact of feedbacks on students learning the instructor was supposed to transcribe the oral communication occurred among participants focusing on the teacher feedback given to the students. It should be considered that not all errors produced by the participants were included in the result of this study. Since the focus of the present study was on frequency of feedback types, at first the tabulated diagram of the feedback types is discussed. Based on Lyster and Ranta's (1997) classification of oral feedback, the result of the transcription demonstrates that from about 25 teacher feedback most of them were related to the oral or interactional feedback provided by the instructor. It might be because of the seniority level of the participants that they preferred to focus on meaning rather than the form. On the other hand, the instructor's concentration was also on negotiated meaning, not on the form.

From about 25 feedbacks provided by the instructor in about half an hour the result showed that $8(32 \%)$ feedbacks were the most used ones related to the 'clarification request', 7 (28\%) feedbacks belong to the 'metalinguistic feedback', 6 (24\%) feedbacks were related to 'recast', 2 (8\%) feedbacks were 'elicitation', and 2 $(8 \%)$ feedbacks were related to the 'repetition'. 'Explicit correction' received no feedback in this study. Some examples on 'clarification request', 'metalinguistic feedback', 'recast', 'clarification', and 'repetition' feedback 
Yousefi, V.

are given below. Table 1 shows the tabulation of frequency feedback types below.

\section{Table 1}

Frequency feedback types

\begin{tabular}{cccccc}
\hline $\begin{array}{c}\text { Clarification } \\
\text { Request }\end{array}$ & $\begin{array}{c}\text { Metalinguistic } \\
\text { Feedback }\end{array}$ & Recast & Clarification & $\begin{array}{c}\text { Repetition } \\
\text { Feedback }\end{array}$ & Repetition \\
\hline 8 & 7 & 6 & 2 & 2 & 0 \\
$32 \%$ & $28 \%$ & $24 \%$ & $8 \%$ & $8 \%$ & $0 \%$ \\
\hline
\end{tabular}

After classroom observation through tape-recording the students were provided to have an interview on the types of feedback they had just received. The follow-up interviews with students demonstrate that there is conformity between their preferences and the actual classroom feedback given.

\section{Clarification Request (an example)}

Student: In that case, instruction needs some explanation and repetition, so children are better in examples and sentences (focusing on induction).

Instructor: Which one induction or deduction?

\section{Metalinguistic Feedback (an example)}

Student: Children are better in this instruction (he means inductive learning).

Instructor: This is your claim and assumption, isn't it?

\section{Recast (an example)}

Instructor: How about children learning second language? Are they better than adults in inductive learning?

Student: yeah, because of critical language ..... .

Instructor: this might be one of the possible answer, but..... .

\section{Clarification (an example)}

Instructor: can you find other areas in which children are better than adults?

Student 1: in receptive / productive processing they are better.

Student 2: sorry, would you please repeat it again.

Instructor: he means..... . Ok. I doubt it.

\section{Repetition Feedback (an example)}

Student: Children are better in induction.

Instructor: No, not in induction. Induction? (with raising intonation)

While the primary focus of oral feedback, as mentioned by Lyster and Ranta (1997), was on the syntactic part of the language, this study attempts to investigate the impact of the oral feedbacks on semantic features of language. When at the end of the session the participants are requested to express their viewpoints on negotiated feedback in term of oral feedbacks, they mostly state that through negotiation they found that the erroneous messages were clarified very quickly and they could realize their problems. 


\subsection{Discussion}

Even though Lyster and Ranta's (1997) classification put emphasis on oral feedback in the structure of languages, this study applied the oral feedback to the meaning of English language learning. In second language acquisition research, Lyster and Ranta (1997) and Lyster (1998) found that recasts are the most common, but least effective, form of oral corrective feedback employed by foreign language teachers. In the present study, however, recast did not receive the highest rank. Instead, because of the purpose of the study, to focus on meaning, the clarification feedback was the most employed one while the repetition feedback was the least employed one.

There are also debates as to whether particular types of CF are more beneficial to L2 learning. For example, some researchers such as Doughty (2003) and Long (2007) argue that recasts are the most effective type of CF in facilitating L2 learning because it serves as a vehicle for helping learners make cognitive comparisons when provided in a so-called window of opportunity immediately following learner errors. But the present study has refuted their finding. Of course it might be because of the meaning-focused essence of this study. Other researchers, however, claim that $\mathrm{CF}$ types that withhold the correct form (e.g., clarification requests, elicitation) are most likely to contribute to development by pushing learners to stretch their interlanguages (Ammar \& Spada, 2006 ; Lyster, 2004 ). Regarding different purposes of the studies, the finding of this study is in line with what Lyster (2004) and Ammar and Spada (2006) found in their studies.

The recent researchers employ operationalized negotiated feedback in terms of a "regulatory scale" consisting of a number of feedback strategies, beginning with broad implicit feedback and gradually moving toward more specific direct/explicit help in a scaffolding manner. Using Aljaafreh and Lantolf's (1994) regulatory scale, a few other research studies (Nassaji, 2007; Nassaji, 2011; Nassaji \& Swain, 2000) were conducted investigating the efficacy of negotiated feedback all of which assert the effectiveness of negotiated feedback. Apart from the content needed to be feedbacked, the finding of this study is more in line with negotiated feedback than other feedbacks concerning language structure.

\section{Conclusion}

Although a lot of studies are conducted on feedback to help learners find their errors underlying syntactic structure for learning enhancement, none of them addressed the semantic features of language in interactional communication to realize the effect of feedback on the students' learning. As the finding of the study revealed, the learners' preferences are mostly clarification oriented when they come to interactional feedback in higher level. Therefore, it can be concluded that no clear border line can be assumed among different feedbacks though the most frequent one has been signified. It is fair to say that the combination of feedbacks in terms of 'regulatory scale' can be employed in the second language learning classroom. The feedback process is eventually a mutual process that each side effects the other and every side can correct themselves as well.

\section{References}

Aljaafreh, A., \& Lantolf, J. (1994). Negative feedback as regulation and second language learning in the zone of proximal development. Modern Language Journal, 78, 465-483. http://dx.doi.org/10.1111/j.1540-4781.1994.tb02064.x

Ammar, A., \& Spada, N. (2006). One size fits all? Recasts, prompts, and L2 learning. Studies in Second Language Acquisition, 28, 543-574. http://dx.doi.org/10.1017/S0272263106060268

Birjandi, P., \& Tabatabaei, O. (2009). The impact of gender on the incidence and quality of form-focused episodes in Task-Based conversational feedback among EFL learners. Asian EFL Journal, 11(4), 220-240.

Chaudron, C. (1988). Second language classrooms: Research on teaching and learning. Cambridge: CUP. http://dx.doi.org/10.1017/CBO9781139524469 
Yousefi, V.

Corder, S. (1967). The significance of learner's errors. IRAL, 5(4), 147-170. http://dx.doi.org/10.1515/iral.1967.5.1-4.161

Doughty, C. J. ( 2003 ). Instructed SLA: Constraints, compensation, and enhancement. In C. J. Doughty \& M. H. Long (Eds.), The handbook of second language acquisition (pp. 256-310). Oxford: Blackwell. http://dx.doi.org/10.1002/9780470756492.ch10

Doughty, C. J., \& Varela, E. (1998). Communicative focus on form. In C. J. Doughty \& J. Williams (Eds.), Focus on form in classroom second language acquisition (pp. 114-138). New York: CUP.

Ellis, R. (2009). A typology of written corrective feedback types. English Language Teaching Journal, 63, 97-107. http://dx.doi.org/10.1093/elt/ccn023

Ellis, R. (2010). A Framework for investigating oral and written corrective feedback. Studies in Second Language Acquisition, 32, 335-349. http://dx.doi.org/10.1017/S0272263109990544

Ferreira, A., Moore, J. D., \& Mellish, Ch. (2007). A study of feedback strategies in foreign language classrooms and tutorials with implications for intelligent computer-assisted language learning systems. International Journal of Artificial Intelligence in Education, 17, 389-422.

Gipps, C. V. (1994). Beyond testing: Towards a theory of educational assessment. Washington D.C.: The Falmer Press.

Gurney, P. (1988). Self-esteem in children with special educational needs. London: Routledge.

Hartshorn, K. J., Evans, N. W., Merrill, P. F., Sudweeks, R. R., Strong-Kkrause, D., \& Anderson, N. J. (2010). Effects of dynamic corrective feedback on ESL writing accuracy. TESOL Quarterly, 44(1), 84-109. http://dx.doi.org/10.5054/tq.2010.213781

Hyland, K., \& Hyland, F. (2006). Feedback on second language students' writing. Language Teaching, 39, 83-101. http://dx.doi.org/10.1017/S0261444806003399

Keshavarz, M. H. (1999). Contrastive analysis and error analysis. Tehran: Rahnama Publications.

Lee, E. J. (2013).Corrective feedback preferences and learner repair among advanced ESL students. System, 41, 217-230. http://dx.doi.org/10.1016/j.system.2013.01.022

Long, M. H. (2007). Recasts in SLA: The story so far. In M. H. Long (Ed.), Problems in SLA (pp. 75-116). Mahwah, NJ: Erlbaum.

Lyster, R. (1998). Negotiation of form, recasts, and explicit correction in relation to error types and learner repair in immersion classrooms. Language Learning, 48(2), 183-218. http://dx.doi.org/10.1111/1467-9922.00039

Lyster, R. (2004). Differential effects of prompts and recasts in form-focused instruction. Studies in Second Language Acquisition, 19, 399-432. http://dx.doi.org/10.1017/s0272263104263021

Lyster, R., \& Ranta, L. (1997). Corrective feedback and learner uptake: Negotiation of form in communicative classrooms. Studies in Second Language Acquisition, 19(1), 37-66. http://dx.doi.org/10.1017/S0272263197001034

Mackey, A. (2012). Input, interaction, and corrective feedback in L2 learning. Oxford: OUP.

Maftoon, P., \& Zareh Ekbatani, A. (2005). A comparative study of two feedback methods on Iranian EFL learners' writing skills. Al-Zahra University Scientific Research Journal of Humanistics, 15, 85-109.

Nassaji, H. (2007). Reactive focus on form through negotiation on learners' written errors. In S. Fotos \& H. Nassaji (Eds.), Form-focused instruction and teacher education: Studies in honour of Rod Ellis (pp. 117-129). Oxford: Oxford University Press.

Nassaji, H. (2011). Correcting students' written grammatical errors: The effects of negotiated versus non-negotiated feedback. Studies in Second Language Learning and Teaching, 1(3), 315-334.

Nassaji, H., \& Swain, M. (2000). Vygotskian perspective on corrective feedback in L2: The effect of random versus negotiated help on the learning of English articles. Language Awareness, 9, 34-51. http://dx.doi.org/10.1080/09658410008667135

Nunan, D. (1991). Language teaching methodology: A textbook for teachers. London: Prentice Hall.

Oliver, R. (2000). Age differences in negotiation and feedback in classroom and pairwork. Language Learning, 50, 119-151. http://dx.doi.org/10.1111/0023-8333.00113

Russell, V. (2009). Corrective feedback, over a decade of research since Lyster and Ranta (1997): Where do we 
stand today? Electronic Journal of Foreign Language Teaching, 6(1), 21-31.

Sadler, R. (1989). Formative assessment and the design of instructional systems. Instructional Science, 18, 119-144. http://dx.doi.org/10.1007/BF00117714

Sheen, Y. (2010). The role of oral and written corrective feedback in SLA. Studies in Second Language Acquisition, 32, 169-179. http://dx.doi.org/10.1017/S0272263109990489

Suzuki, M. (2004). Corrective feedback and learner uptake in adult ESL classrooms. Columbia University Working Papers in TESOL \& Applied Linguistics, 4, 1-21.

Thornbury, S. (2006). An A-Z of ELT. Oxford: Macmilan Education.

Vigil, N., \& Oller, J. (1976). Rule fossilization: A tentative model. Language Learning, 26, 281-295. http://dx.doi.org/10.1111/j.1467-1770.1976.tb00278.x

Weissberg, R. (2006). Scaffolded feedback: Tutorial conversations with advanced L2 writers. In K. Hyland, \& F. Hyland (Eds.), Feedback in second language writing: Contexts and issues (pp. 246-265). New York: Cambridge.

Winne, P. H., \& Butler, D. L. (1994). Student cognition in learning from teaching. In T. Husen \& T. Postlewaite (Eds.), International encyclopedia of education (pp. 5738-5745). Oxford: Pergamon. 
Yousefi, V. 